\title{
The impact of government R\&D support on SMEs financial growth: Evidence from China
}

\author{
Hongxing Peng ${ }^{1,2, *}$, Yingmin $\mathbf{Y u}^{1}$ \\ ${ }^{1}$ School of Accountancy, Central University of Finance and Economics, Beijing, China \\ ${ }^{2}$ Sidhu School of Business, Wilkes University, Wilkes-Barre .PA, U.S.A \\ Email address: \\ redstarcufe@hotmail.com (H. Peng), yuym168@126.com (Y. Yu)
}

To cite this article:

Peng, H., Y. Yu. The Impact of Government R\&D Support on SMEs Financial Growth: Evidence from China. International Journal of Economics, Finance and Management Sciences. Vol. 1, No. 5, 2013, pp. 205-214. doi: 10.11648/j.ijefm.20130105.11

\begin{abstract}
This paper investigates the impact of government R\&D support on financial growth of SMEs, and analyzes the significant different supportive effect for the enterprises with different nature of control rights. We take 516 listed companies from the SMEs' board on Shenzhen stock market as sample, using the data from 2006 to 2011 and implementing the method of Propensity Score Matching to relieve the sample selection bias. The empirical results indicate that: On the whole, government R\&D support can effectively improve the financial growth of SMEs, and demonstrates an 1-2 year-lagged-effect; the property of enterprises' ultimate controller also has extraordinary impact on R\&D supportive effect, financial growth of non-state-holding companies which have accepted R\&D support will turn out to be more significant improvement, while that of the state-controlled enterprises have not been significantly enhanced in the short-term, or even fared-worse than the matched samples.
\end{abstract}

Keywords: Government R\&D Support, SMEs, Financial Growth, Propensity Score Matching

\section{Introduction}

In this article we aim to understand the effectiveness of these government R\&D supportive policies by using in-sights from both economic theory and statistic model. SMEs play an increasingly important role in promoting urbanization, creating jobs, increasing tax revenue, enhancing technological innovation and regional economic development and so on. However, SMEs are faced with growth bottlenecks from aspects of management, capital, innovation and so forth; governments have attached great importance to support SMEs, especially for SMEs' R\&D activities. In recent years, the Ministry of Finance, Ministry of Science and other central ministries coordinated with local government departments has set up hundreds of SMEs support programs to promote SMEs' R\&D in China, including SMEs Technology Innovation Fund, technology incentives and tax concessions and so forth. Prior literatures have studied these policies effectiveness in pro-moting the firm's R\&D investment or increasing the company's innovation output, but the research literature from the perspective of corporate financial growth is still uncommon, we attempt to apply Propensity Score Matching method to test the validity of the government
R\&D supportive policies. Can the policies significantly improve SMEs financial growth; will the ownership properties cast a significant difference on the policy validity? By doing so, our concerns may help the government construct a wide range of more effective policies for SMEs' R\&D activities, and also promote SMEs to take the $R \& D$ incentives seriously to increase $R \& D$ investment, improve product technological content and cultivate better-established brands.

Compared with the relevant literature, the innovation lies in this article as follow: (1) Enriching the relevant literature by testing the effectiveness of government R\&D support policies from the financial growth perspective; (2)Using 516 micro-enterprises financial data from 2006 to 2011 on the background of Chinese market to implement empirical analysis, it is still so far the largest number of observations within the similar studies, a larger sample of data probably can effectively improve the credibility of research conclusions; (3)Alleviating concerns about the endogeneity problem which might be caused by sample selection bias, that is the government may be more inclined to choose the blue-chip companies when allocating the $\mathrm{R} \& \mathrm{D}$ supportive resources, we implement the propensity score matching method (hereinafter referred to as "PSM"), thus we reconcile the biased problems that probably occurred in 
traditional parametric tests and improve the credibility and robustness of research implications; (4)In order to test the ownership propriety effect on the support policies, we further discuss the relationship between the financial growth performance and the support policies among the SMEs with different types of controlling ownership.

The rest of the paper is organized as follows: Section 2 discusses the drafting of the issues and the related literature; Section 3 shows the research design and elaborates on the concept of the PSM that is used for the empirical analysis; Section 4 presents the empirical results; and Section 5 closes with a summary of the main results.

\section{Literature Review}

The issue on the government support validity has been much concern for scholars, there is a bulk of archival literatures in the area. SMEs are confronted with obstacles from many aspects. On one hand the SMEs hold smaller operational size, lower management level, relatively higher tax burden, which is leading to lack of internal capital accumulation, while external financing channels for SMEs are also narrower (Lerner, 2002 ${ }^{[27]}$ ); On the other hand, because of the technology and knowledge spillovers effect, R\&D activities will inevitably encounter market failure and underinvestment problem (Arrow, 1962 ${ }^{[1]}$; Tassey, 2004 ${ }^{[38]}$ ). To this end, scholars agree that it is necessary for the government to provide subsidies and tax concessions and other preferential in order to support R\&D activities. Although the government-supported R\&D activities can enhance innovation capability, these supportive validity may also be greatly reduced due to government rent-seekers during the implementation (Klette et al. $2000^{[26]}$ ), the effectiveness of the government supportive policies should be a more important issue, relevant departments need to pay more attention to and evaluate the specific implementation validity of the government R\&D support for SMEs(Corley, 2007 $7^{[7]}$ ), or else the funds that are designed to enhance the ability of the private sector R\&D will have been wasted(Hsu et al. 2009 ${ }^{[21]}$ ).

Theoretical framework and systematical research methods on evaluating the effectiveness of SMEs supportive policies are not yet perfect, meanwhile, coupled with difficulties in collecting data and distinguishing external interference factors, the prior relevant studies are still not in full swing, and mainly carried out from the point of corporate R\&D investment (Wallsten, 2000 ${ }^{[39]}$ ), new product output ( $\mathrm{Li}$ et al. $2012^{[29]}$ ), patents output (Colombo, $2009^{[8]}$ ). After the newly-developed product being put on the market, the financial performance of the enterprise is bound to make reaction, to the best of our knowledge, the relevant study from a financial perspective specifically considering effects of government R\&D support is still rare. Many indicators to evaluate and measure business growth performance, such as business revenue growth, number of employees growth, profits growth, market share growth, etc. (Boardman et al. 1981 ${ }^{[3]}$; Konings, 1997 ${ }^{[23]}$; 2002 $2^{[25]}$; Grilli et al. $2009^{[8]}$; Hsu et al. $2009^{[21]}$ ).

Financial growth is affected by many factors, innovation capability of enterprise plays an important role in its growth (Penrose, 1959 ${ }^{[32]}$ ); firm size, the quality of managers and corporate business strategies are also crucial factors for SMEs financial growth. Additionally, the business life cycle, size or ownership propriety, external financing constraints, the legal system and other factors also affect the financial growth of enterprises (Storey, 1994 ${ }^{[36]}$; Becchetti et al. 2002 $2^{[4]}$; Alecke et al.2011 ${ }^{[2]}$ ). Only effectively control these factors that might influence corporate financial growth performance can we evaluate the effectiveness of the support.

Former scholars hold quite different opinions on the empirical results. Some scholars believe that the government's R\&D for SMEs support policies to be effective. Hsu et al. $\left(2009^{[21]}\right)$ employs the nine years of data from 110 Taiwan government support projects and concludes that technology productivity of enterprises that get government support is significantly better than that are not supported; Czarnitzki (2011 ${ }^{[10]}$ ) finds that R\&D tax credit significantly promote the company's innovative product yields using a sample of manufacturing firms from Canada. Foreman-Peck $\left(2012^{[16]}\right)$ argues that the UK government-supported SMEs' innovation performances significantly are higher than the samples without support. Grilli et al. $\left(2012^{[20]}\right)$ holds that high-tech company's sales revenue and employee growth rate are significantly higher than other similar enterprises, using the data from EU member countries. For Chinese scholars (Zhu et al. 2003 ${ }^{[42]}$, Xiao et al. 2007 $7^{[40]}$; Yuan et al. 2012 $2^{[41]}$ ) also believe that the government supportive policies play an important role in the process of SMEs technological innovation. However, some scholars are not optimistic about the effectiveness of the government R\&D support programs. Goolsbee et al. $\left(1998^{[17]}\right)$ argues that the R\&D funds that government's support for private sector do increase researchers wage levels but still supplant the private sector's innovation output; Wallsten $\left(2000^{[39]}\right)$ finds that the U.S. corporate tax incentives for SMEs have extruding effect on R\&D yields; Marcus and Howard $\left(2003^{[30]}\right)$ do not find evidence that selective R\&D subsidies activity will have a significant impact on innovation productivity from the background of the Japan and South Korea's industrial policies implementation; there is serious dislocation between the expectation of government support policies and the actual effect (Chen et al. 2005 ${ }^{[11]}$; Gu et al. 2006 ${ }^{[19]}$ ) .

The main difficulty in evaluating the effectiveness of government R\&D support lies in the non-random selection when choosing the support object and result in the endogeneity problem, even if the final conclusion that financial growth of supported enterprise is significantly higher than that is unsupported, we still cannot argue that the better growth performance stems from government R\&D support, it is likely that only those high-growth companies can benefit from government support policies. Thus, the estimated results according to the traditional 
method of parameter estimation will be biased, which is widely concerned in the extant literature. Multi-stage regression is widely accepted to decrease this type of endogeneity problem, but there is a big difficulty in instrumental variables selection. As PSM developed in recent years, some studies begin to take its advantage to deal with such selection-bias problem (Rubin et al. 1977 ${ }^{[33]}$; Herrera et al. $2010^{\text {[22]; Czarnitzki, 2011 }}{ }^{[10]}$; Giovanni Cerulli, 2012 ${ }^{[12]}$ ).

In summary, our results help reconcile the inconsistent prior findings concerning government R\&D support policies. We aim to extend the related researches from the point of financial growth performance by adopting the increasingly sophisticated approach PSM. This paper also considers the externality and government intervention (Arrow, 1962 ${ }^{[1]}$; Lerner, 2002 $2^{[27]}$ ) and it provides additional evidence on the effects of corporate ownership propriety on the financial performance (Kole et al.1997 ${ }^{[22]}$; Boubakri et al. $2005^{[5]}$ ).

\section{Research Design}

\subsection{Data and Sample Selection}

This article combines financial data from Wind, CSMAR and RESSET; the data regarding government support for SMEs' R\&D is manually retrieved from the annual reports. Taken the fact that there might be some sample database mistakes and errors in statistical; we make the following selection of the sample data: (1) Excluding the observations with missing data records of the variable, such as net assets per share growth rate, total asset turnover ratio, total revenue growth rate, operating profit growth rate, growth rate of net assets, total assets growth rate; (2) Excluding the samples whose asset-liability ratio is more than 1 , that is insolvent enterprises; (3)Excluding the observations where the total asset growth exceeding $150 \%$, in order to eliminate the interference arising from mergers and acquisitions; (4) Excluding the company data of listed year, in order to reduce shocks arising from the possible earnings management due to listing; (5) Excluding companies in finance and ST/PT classes. Besides, we winserize the main variables (excluding dummy variables) on the level of $1 \%$ and $99 \%$, in order to mitigate the interference of the outliers.

We split sample enterprises into two categories (nonstate-holding enterprises and state-controlled enterprises) according to the nature of ultimate control ownership rights. Seen from Table 1, the numbers of state-controlled and non-state-holding enterprises are both increasing year by year, but the proportion of state holding enterprises is declining, accounting for a minimum of $17.84 \%$ and a maximum of $30.53 \%$, indicating that Chinese government has paid attention to the economy privatization. 516 small board listed companies range from a total of 12 industries ${ }^{1}$,

1 Classified by the Chinese SFC Industry Classification Standard
$75 \%$ of enterprises are in the manufacturing sector, the information industry accounts for about $10 \%$, all other industries make up no more than $5 \%$.

Table 1. 2006-2011 Sample Enterprises Distribution

\begin{tabular}{llllll}
\hline $\begin{array}{l}\text { Panel A: } \\
\text { Year }\end{array}$ & $\begin{array}{c}\text { By Non-State } \\
\text { dComp }\end{array}$ & Prop(\%) & $\begin{array}{l}\text { Stated } \\
\text { Comp }\end{array}$ & Prop(\%) & Totally \\
\hline 2006 & 35 & 76.09 & 11 & 23.91 & 46 \\
2007 & 66 & 69.47 & 29 & 30.53 & 95 \\
2008 & 135 & 71.81 & 53 & 28.19 & 188 \\
2009 & 193 & 74.52 & 66 & 25.48 & 259 \\
2010 & 237 & 76.21 & 74 & 23.79 & 311 \\
2011 & 419 & 82.16 & 91 & 17.84 & 510 \\
\hline \hline
\end{tabular}

\begin{tabular}{|c|c|c|c|c|c|}
\hline Panel B: By Industry & No. & $\operatorname{Prop}(\%)$ & Industry & No. & $\operatorname{Prop}(\%)$ \\
\hline Agriculture & 10 & 1.94 & IT industries & 51 & 9.88 \\
\hline Extractive industries & 5 & 0.97 & Retailing & 16 & 3.10 \\
\hline Manufacturing & 392 & 75.97 & $\begin{array}{l}\text { Real estat } \\
\text { development\& } \\
\text { management } \\
\text { industries }\end{array}$ & 6 & 1.16 \\
\hline $\begin{array}{l}\text { Electricity, gas \& water } \\
\text { production \& supply } \\
\text { industry }\end{array}$ & & 0.58 & $\begin{array}{l}\text { Tourism,social } \\
\text { services }\end{array}$ & 12 & 2.33 \\
\hline Building industry & 13 & 2.52 & Public utilities & 2 & 0.39 \\
\hline $\begin{array}{l}\text { Transportation } \\
\text { warehousing }\end{array}$ & 5 & 0.97 & Comprehensive & 1 & 0.19 \\
\hline
\end{tabular}

Source: Collected from Wind database

\subsection{The Basic Idea for PSM}

It's impossible for the given SEM to be supported and unsupported in the same period; therefore, comparing the growth differences between the two states is generally not feasible, like doing experiments research, only one state can be observed, while the other is counterfactual. In order to solve this problem caused by the unobserved performance, Rubin et al. $\left(1977^{[33]}\right)$ propose matching method, the basic idea is that if you can find a control group that is as similar as possible to the supported, it would be sufficiently reduce sample selection bias, when evaluating the effectiveness of the policies. However, judging from one particular feature (such as size) often cannot be sufficient to achieve the satisfied matching effect in the process of matching the control group. Therefore, PSM method condenses a plurality of characteristic factors into one single indicator, the propensity score values (referred to as PS values), enables multi-dimensionality reduction matching. Rosenbaum \& Rubin $\left(1983^{[34]}\right)$ estimate the Logistic model to obtain the probability $\left(p\left(\mathrm{X}_{i}\right)\right)$ that can receive government $\mathrm{R} \& \mathrm{D}$ support and to match the treated and controlled groups.

$$
p\left(\mathrm{X}_{i}\right)=\operatorname{Pr}\left[\mathrm{D}_{i}=1 \mid \mathrm{X}_{i}\right]=\mathrm{E}\left[D_{i} \mid \mathrm{X}_{i}\right]
$$

Where $\mathrm{X}_{i}$ is the vector of characteristics variables that count on receiving the support polices or not, $\mathrm{D}_{i}$ is the 
indicator variable ( $=1$, be supported; $=0$, otherwise). ATT (Average effect of treatment on the treated) is the key indicator that can test the different performance of the supported and control group (Becker and Ichino, 2002 $2^{[6]}$ ),

$$
\begin{aligned}
\mathrm{ATT} & =\mathrm{E}\left[\mathrm{Y}_{1 i}-\mathrm{Y}_{0 i} \mid \mathrm{D}_{i}=1\right] \\
& =\mathrm{E}\left\{\mathrm{E}\left[\mathrm{Y}_{1 i}-\mathrm{Y}_{0 i} \mid \mathrm{D}_{i}=1, p\left(\mathrm{X}_{i}\right)\right]\right\} \\
& =\mathrm{E}\left\{\mathrm{E}\left[\mathrm{Y}_{1 i} \mid \mathrm{D}_{i}=1, p\left(\mathrm{X}_{i}\right)\right]-\mathrm{E}\left[\mathrm{Y}_{0 i} \mid \mathrm{D}_{\mathrm{i}}=0, p\left(\mathrm{X}_{i}\right)\right] \mid \mathrm{D}_{i}=1\right\}
\end{aligned}
$$

Where $\mathrm{Y}_{1 i}$ and $\mathrm{Y}_{0 i}$ represent the performance of supported and controlled groups respectively.

\subsection{Matching Methods}

We cannot estimate the ATT of interest by directly using (2) even though the propensity scores have been estimated. The reason is that $p\left(\mathrm{X}_{i}\right)$ is a continuous variable, and thus it is impossible to find two units with identical propensity score (Lian et al. 2011 ${ }^{[28]}$ ). The most widely used matching methods are Nearest-Neighbor Matching, Radius Matching and Kernel Matching.

The nearest neighbor matching method is to look both forward and backward for the $j^{\text {th }}$ sample from the control group to match the supported samples by judging the PS values estimated by the probability model. Let $p_{i}^{\mathrm{S}}$ and $p_{j}^{\mathrm{C}}$ represent the estimated propensity score value of the supported and controlled group, respectively. Then, the nearest neighbor $j$ can be described as follows,

$$
C(j)=\min \left\|p_{i}^{\mathrm{T}}-p_{j}^{\mathrm{S}}\right\|
$$

Similarly, the radius matching method is to search all samples in the control group, and whose PS falls within a radius $r$ from $p_{i}{ }^{\mathrm{T}}$ are matched to the supported sample $i$. The matching principle is as,

$$
C(j)=\left\{\left\|p_{i}^{\mathrm{T}}-p_{j}^{\mathrm{S}}\right\|<r\right\}
$$

We can calculate ATT if the matched samples are identified according to Becker and $\operatorname{Ichino}\left(2002^{[6]}\right)$.

\subsection{Variables Definition}

The propensity score on SMEs' access to achieve government R\&D support are required to estimate prior to implement PSM non-parametric test. In this paper, we adopt the Logitstic probability model to calculate propensity scores consistent with (Dehejia and Wahba, $\left.2002^{[14]}\right)$. Business performance, R\&D expenditures, asset size, number of employees, the listed age, industry characteristics (Czarnitzki, 2006 ${ }^{[9]}$; 2011 ${ }^{[10]}$; Giovanni Cerulli, 2012 $2^{[12]}$ ) and other characteristical variables are all the key factors that affect the probability to obtain government support. According to the existing theoretical and empirical research findings, the characteristical variables selected are shown in Table 2.

\section{Empirical Results}

\subsection{Descriptive Statistics}

Seen from Table 3, in addition to employees, Tobin's q is of two and three missing values, respectively, other variables are all of no missing observation holding number of 1409. The standard deviation of characteristical variables is less than 3.5, except for net asset per share growth rate, size, number of employees and other variables, indicating that these characteristical variables fluctuate slightly, the difference between the mean and the median is also not large, and we can approximately assume these variables are normally distributed. Total operating income growth rate and other variables that reflect the SMEs' financial growth hold large variances, suggesting the mean and median are significantly differently, it's usually considered that these variables do not obey symmetrical distribution, so these variables are not put into the Logistic model to calculating

\begin{tabular}{|c|c|c|}
\hline Name & Symbol & Definition \\
\hline Size & ata & natural logarithm of the total assets \\
\hline Employees & lnemp & natural logarithm of the employees \\
\hline Listed age & lnage & $\begin{array}{l}\text { natural logarithm of months from } \\
\text { the listed date }\end{array}$ \\
\hline $\mathrm{R} \& \mathrm{D}$ expenditure & lnrdex & $\begin{array}{l}\text { natural logarithm of the } R \& D \\
\text { expenditure }\end{array}$ \\
\hline Adjusted profits & adprofit & $\begin{array}{l}\text { cash flow from operational } \\
\text { activities/ total assets }\end{array}$ \\
\hline Ownership & shrcr3 & $\begin{array}{l}\text { top three largest shareholder's } \\
\text { ownership }\end{array}$ \\
\hline $\begin{array}{l}\text { Net assets per } \\
\text { share growth rate }\end{array}$ & ncapsg & $\begin{array}{l}\text { (net assets per share at end of } t-n e t \\
\text { assets per share at the end of } t-1 \text { )/ } \\
\text { net assets per share at the end of } t-1\end{array}$ \\
\hline $\begin{array}{l}\text { Total assets } \\
\text { turnover }\end{array}$ & rat & $\begin{array}{l}\text { net operational income/average total } \\
\text { assets }\end{array}$ \\
\hline $\begin{array}{l}\text { Return on total } \\
\text { assets }\end{array}$ & roa & net profits /average total assets \\
\hline Return on equity & roe & net profits /average equity \\
\hline $\begin{array}{l}\text { Market-to-book of } \\
\text { equity }\end{array}$ & tobinq & $\begin{array}{l}\text { market value of equity/book value } \\
\text { of equity }\end{array}$ \\
\hline Industry & Industry & 11 industry dummy variables \\
\hline
\end{tabular}
propensity scores, but the fact that asymmetrical distribution and greater volatility does not affect the estimates of ATT after matching.

Table 2. Variables Definition

\subsection{Logistic Regression Model}

We employ Logistic regression model to calculate the propensity score, i.e. the probability that the samples can obtain government R\&D support, and government may examine the past condition of candidates when it allocates the supportive resources. Therefore, in this paper we select one-and-two lagged characteristical variables to estimate Logistic regression model, as described in equation (5),

$$
p\left(\mathrm{X}_{i}\right)=\operatorname{Pr}\left[\operatorname{supp}_{t} \mid \mathrm{X}_{t-1}\right]=\exp \left(\beta \mathrm{X}_{t-1}\right) /\left(1+\exp \left(\beta \mathrm{X}_{t-1}\right)\right)
$$

Where supp $_{t}$ indicates whether a company receives government $\mathrm{R} \& \mathrm{D}$ support in $\mathrm{t}$ year $(=1$, supported; $=0$, otherwise); $\mathrm{X}_{t-1}$ (or $\mathrm{X}_{t-2}$ ) represents the vector of characteristical variables in $\mathrm{t}-1$ (or $\mathrm{t}-2$ ) year, $\beta$ indicates the regression coefficients for characteristical variables. 
We present the regression results of Logistic model in Table 4, both Pseudo- ${ }^{2}$ and AUC (Stein et al. 2005 ${ }^{[37]}$; Okeh, 2012 $2^{[31]}$ ) are considered to evaluate the goodness of fit of the model. Judging from the model that employs one-year-backward or two-year-backward characteristical variables, we could see the coefficients of asset size is significantly negative $(p<0.01)$, indicating that the smaller enterprises are more likely to be supported in China, which is opposite to the conclusions from Herrera et al. $\left(2010^{[22]}\right)$ and Dirk Czarnitzki $\left(2011^{[10]}\right)$. That's probably for the reason that the $R \& D$ support budget from Chinese government is still not high, compared with smaller SMEs, the larger-scale ones might operate in relatively better condition and keep stronger capital and technology strength and higher motivation to R\&D activities, policy-makers are more inclined to support the enterprises with smaller asset size; this may also be due to the smaller companies faced with greater financial constrains, technical development bottlenecks, and have more incentives to apply for R\&D support.

Table 3. Variables Descriptive Statistics

\begin{tabular}{|c|c|c|c|c|c|c|c|c|}
\hline & Varibles & Symbol & $\mathbf{N}$ & Mean & S.D & Min & Med & $\operatorname{Max}$ \\
\hline \multirow{12}{*}{ 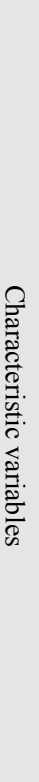 } & Dummy & supp & 1409 & 0.47 & 0.50 & 0.00 & 0.00 & 1.00 \\
\hline & Size & $\ln t a$ & 1409 & 7.29 & 0.79 & 5.82 & 7.21 & 9.68 \\
\hline & Employee & $\operatorname{lnemp}$ & 1407 & 7.31 & 0.88 & 5.37 & 7.29 & 9.41 \\
\hline & Listed age & lnage & 1409 & 3.24 & 0.62 & 2.49 & 3.18 & 4.43 \\
\hline & $\begin{array}{c}\text { R\&D } \\
\text { expenditure }\end{array}$ & lnrdex & 1409 & 5.95 & 3.36 & 0.00 & 7.38 & 9.84 \\
\hline & $\begin{array}{l}\text { Adjusted } \\
\text { profit }\end{array}$ & adprofit & 1409 & 1.21 & 2.86 & -7.06 & 0.62 & 46.24 \\
\hline & Ownership & shrcr3 & 1409 & 0.54 & 0.13 & 0.23 & 0.55 & 0.84 \\
\hline & $\begin{array}{l}\text { Net assets per } \\
\text { share growth } \\
\text { rate }\end{array}$ & ncapsg & 1409 & -5.59 & 27.44 & -73.84 & 0.00 & 143.20 \\
\hline & $\begin{array}{l}\text { Total assets } \\
\text { turnover }\end{array}$ & rta & 1409 & 0.79 & 0.46 & 0.18 & 0.68 & 2.76 \\
\hline & $\begin{array}{l}\text { Return on } \\
\text { total assets }\end{array}$ & roa & 1409 & 0.06 & 0.05 & -0.08 & 0.06 & 0.24 \\
\hline & $\begin{array}{l}\text { Return on } \\
\text { equity }\end{array}$ & roe & 1409 & 0.10 & 0.07 & -0.16 & 0.09 & 0.31 \\
\hline & $\begin{array}{c}\text { Maket-to-boo } \\
\text { k of equity }\end{array}$ & tobinq & 1406 & 3.17 & 1.94 & 1.07 & 2.59 & 11.30 \\
\hline \multirow{4}{*}{ 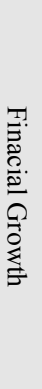 } & $\begin{array}{l}\text { Total } \\
\text { operating } \\
\text { income } \\
\text { growth rate }\end{array}$ & oprg & 1409 & 23.37 & 26.55 & -32.70 & 20.54 & 110.20 \\
\hline & $\begin{array}{l}\text { Operating } \\
\text { profit growth } \\
\text { rate }\end{array}$ & oprog & 1409 & 23.94 & 168.30 & -666.30 & 14.44 & $\begin{array}{c}1134.0 \\
0\end{array}$ \\
\hline & $\begin{array}{l}\text { Net assets } \\
\text { growth rate }\end{array}$ & ncag & 1409 & 16.37 & 28.43 & -15.63 & 7.49 & 155.50 \\
\hline & $\begin{array}{l}\text { Total assets } \\
\text { growth rate }\end{array}$ & $\operatorname{tag}$ & 1409 & 20.05 & 22.37 & -15.86 & 14.24 & 104.00 \\
\hline
\end{tabular}

The impact from corporate employees size is insignificant; Newly listed SMEs have more access to get favorable government support policies; the coefficient of
R\&D expenditures in Panel A regression 2 is significant positive at $10 \%$ level, but the coefficients are not significant in the other regressions; what's more, we can be sure that government $R \& D$ support is positively correlated with corporate past financial performance, adjusted profits can significantly increase the probability of obtaining government support, when taking return on total assets and return on net assets as proxies, although coefficients are not significant in Panel A, the two-year-backward coefficients of these variables are significantly positive $(p<0.01)$, which gives evidence that Chinese government pays more attention to the profitability of enterprises. This may be because enterprises with better earnings can bring more tax revenue to the government; one-year-backward shareholders' ownership shows no significant effect on getting the support, but more concentrated two-year-backward ownership would reduce the likelihood of getting government support. In all models, the coefficients of Tobin's q are significantly negative $(p<0.01)$, suggesting that the enterprises with higher market value are less likely to obtain support, it is possible that for the listed company, the higher market value of the enterprise, the easier to be financed by the market, the relatively weaker financial constraints.

\subsection{Samples Matching Results}

We take both lagged one- and two-year characteristical variables into consideration when calculating the kernel density; and the density of PS value before and after samples matching from supported and controlled groups is presented in Figure 1.
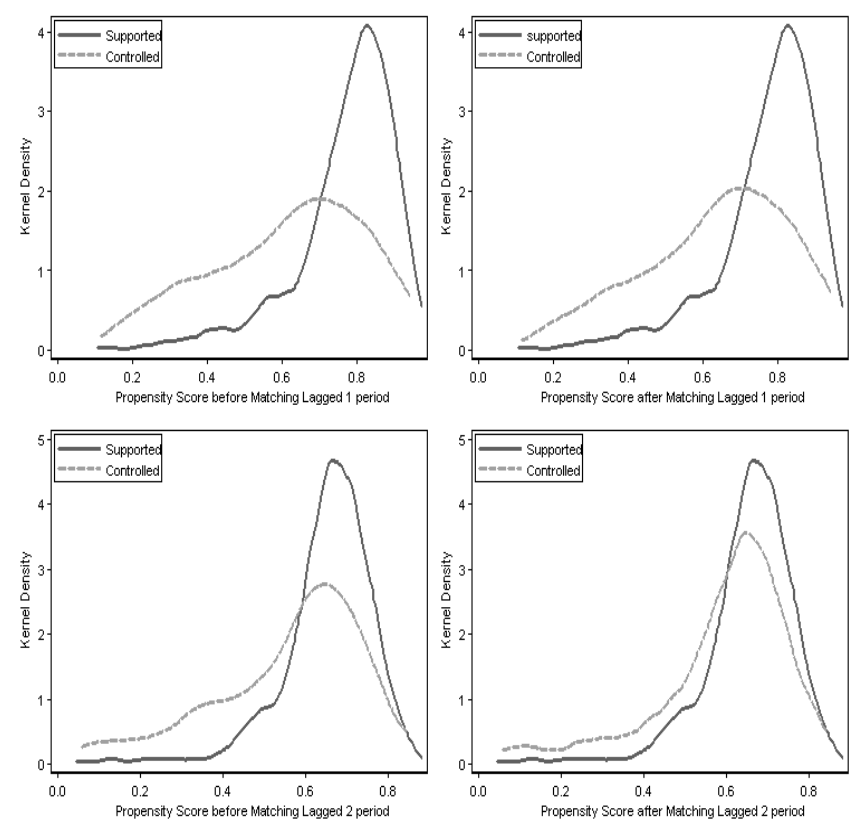

Figure 1. The Kernel Density Function Curves of Propensity Score

Compared with the first two matched groups, there is no denying that their density function curves of PS values are different, which suggests the controlled samples might 
involve certain degree of inappropriate information, and lead to a big different distribution to the supported samples. If no effective method is taken into consideration, the statistical inference judged from direct comparison of these two sets of samples data would be necessarily biased. After matching, the kernel density distribution of the two samples becomes more similar, which means, to some extent, the similarity of their PS values has been improved, especially for the case of the two-year-backward model. Results generated by using radius and kernel matching are similar, not repeat them herein.

\subsection{Analysis of Average Treatment Effect}

To improve the robustness of the conclusions, we employ the three aforementioned matching methods in estimating the sample average treatment effect, the test results are shown in Table 5 Panel $\mathrm{A}, \mathrm{B}$ and $\mathrm{C}$, respectively. It probable that there is time lag effect for the government support policies, thus, we implement one- and two-year government support variables in propensity score matching model.

According to post-matching results from total samples, in the case of lagged-one-period, total revenue growth rate (oprg) of the supported samples, on average, is of 1-3 percentage points higher than that of controlled group, but not significant; for the case of lagged-two-period case, it's of significant higher 7-9 percentage points for the supported. For the operating profit growth rate (oprog), there is a average-higher 35-43 percentage points for the supported group in the lagged-one-period case, but in the lagged-two-period case, the difference between the two turns to the reversed direction, i.e. the supported samples hold a lower operating profit growth rate, on average, than the controlled (unsupported) ones, that's probably because that the companies will do large-scale R\&D investment during 1-2 years from receiving the support, result in a lower operating profit growth rate. When using the nearest neighbor matching method, ATT of net assets growth rate (ncag), is negative at the level of $1 \%$, and not significant in the other two methods; the total assets growth rate (tag) between the two groups is of no significant difference after receiving the support one-year later, but after two years from obtaining government support, the total assets growth rate will be higher than that of controlled group by 3-4 percentage points.

Firms with government intervention and control rights are not conducive to maximize shareholder value and associated with high rents seeking, agency costs. To further analyze the effect of final ownership control rights on the effectiveness of government R\&D support, all samples are classified into two categories by their ultimately controlled rights, i.e. state-controlled enterprises and non-state-holding enterprises. Seen from the lower parts of Table 5, for non-state-holding enterprises, total operating revenue growth rate difference between the supported and controlled groups is not significant after obtaining the support one year, but after being supported two years, the supported group's growth rate is significantly higher by about 10 percentage points. One-period-lagged operating profit growth rate between the two groups is significantly and positively different, while the case for two-period-lagged is not significant, indicating that the supported companies continue to increase R\&D investment and lower the operating profit growth rate. The net assets growth rate of supported group is not significantly higher than that of the controlled after being supported one year, or even on average fared-worse than the control group, but after obtaining government support two years later, it's significantly higher for the supported, which demonstrates the effectiveness of the policies. When it comes to total assets growth rate, the situation is similar to net asset growth rate, once again suggests that government supportive policies behave time lag effect.

For state-owned holding companies, in the nearest neighbor and kernel matching approach, we find the counter-intuitive fact that total revenue growth rate from the supported samples is, on average, significantly lower than that of the control enterprises after one year being supported, besides, whether the support lagged one or two period, for total profit and net asset growth rate, the average treatment effect (ATT) differences between the two groups are not significant, which is probably attributed to state-controlled enterprises are usually of larger assets, located in high-end manufacturing, higher industry risk level, longer product development cycle and relatively larger investment scale. Therefore, the government support still cannot significantly improve their financial growth in the relatively short period.

\section{Conclusions}

The paper examines the impact of government $R \& D$ support on the financial growth of SMEs. On the base of investigating the characteristics of SMEs that might affect their access to the support, we employ propensity score matching (PSM) to undermine the sample selection bias. The empirical results lead to two important implications, (1) The younger and smaller companies are more likely to get government $R \& D$ support, and larger-scale of past $R \& D$ investment can significantly increase the probability of their access to government support; what's more, corporate earnings performances act as key factors in obtaining R\&D support, the higher adjusted profits level, the return on total assets or net assets, the bigger chance to acquire the support; In contrast, the higher market value of SMEs, the less likely to be supported. (2) Judging from the total sample enterprises, the government $R \& D$ support policies play significant and positive role in promoting the financial growth of SMEs, but validity of these supportive policies manifests at least one-year-lagged effect; the paper also shed light on the effect of ultimate control rights in the process of implementing these incentive policies, financial performance of the non-state-controlled enterprises is more ideal, while the state-holding enterprises still make no big 
difference in terms of financial growth during 1-2 years from being supported, which gives evidence that the government controlled SMEs are of low economic efficiency, neglecting their unique characteristics.

Table 4. Logistic Regression Results from $R \& D$ support and firm characteristics

\begin{tabular}{|c|c|c|c|c|c|c|c|c|}
\hline & \multicolumn{4}{|c|}{ Panel A: Lag one period } & \multicolumn{4}{|c|}{ Panel B: Lag two period } \\
\hline & Regression 1 & Regression 2 & Regression 3 & Regression 4 & Regression 1 & Regression 2 & Regression 3 & Regression 4 \\
\hline \multirow[t]{2}{*}{$\operatorname{lnta}$} & $-0.483^{* * *}$ & $-0.538 * * *$ & $-0.449 * * *$ & $-0.482 * * *$ & $-0.590 * * *$ & $-0.545^{* * *}$ & $-0.435 * * *$ & $-0.474 * * *$ \\
\hline & $(-3.52)$ & $(-3.81)$ & $(-3.48)$ & $(-3.66)$ & $(-3.28)$ & $(-2.98)$ & $(-2.60)$ & $(-2.80)$ \\
\hline \multirow[t]{2}{*}{ lnemp } & -0.044 & 0.016 & 0.021 & 0.023 & 0.105 & 0.055 & 0.081 & 0.074 \\
\hline & $(-0.44)$ & $(0.16)$ & $(0.20)$ & $(0.23)$ & $(0.83)$ & $(0.42)$ & $(0.61)$ & $(0.56)$ \\
\hline \multirow[t]{2}{*}{ lnage } & $-0.709 * * *$ & $-0.673 * * *$ & $-0.647 * * *$ & $-0.702 * * *$ & $-1.036^{* * *}$ & $-0.995 * * *$ & $-0.946 * * *$ & $-0.999 * * *$ \\
\hline & $(-5.06)$ & $(-4.63)$ & $(-4.44)$ & $(-4.94)$ & $(-5.38)$ & $(-5.06)$ & $(-4.79)$ & $(-5.17)$ \\
\hline \multirow[t]{2}{*}{ lnrdex } & & $0.039^{*}$ & 0.035 & 0.033 & & -0.023 & -0.033 & -0.028 \\
\hline & & $(1.72)$ & $(1.52)$ & $(1.45)$ & & $(-0.88)$ & $(-1.22)$ & $(-1.04)$ \\
\hline \multirow[t]{2}{*}{ adprofit } & $0.067^{*}$ & $0.075^{* *}$ & & & $0.160 * * *$ & $0.163 * * *$ & & \\
\hline & $(1.88)$ & $(2.04)$ & & & $(2.82)$ & $(2.81)$ & & \\
\hline \multirow[t]{2}{*}{ shar3 } & 0.707 & 0.862 & 0.860 & 0.880 & $-1.412 *$ & $-1.568^{*}$ & $-1.613^{*}$ & $-1.554^{*}$ \\
\hline & (1.16) & (1.39) & (1.39) & $(1.42)$ & $(-1.77)$ & $(-1.92)$ & $(-1.94)$ & $(-1.90)$ \\
\hline \multirow[t]{2}{*}{ ncpsg } & & -0.004 & -0.005 & & & -0.006 & $-0.007 *$ & \\
\hline & & $(-1.50)$ & $(-1.62)$ & & & $(-1.55)$ & $(-1.91)$ & \\
\hline \multirow[t]{2}{*}{ rat } & & $-0.407 * *$ & $-0.426 * *$ & $-0.432 * *$ & & 0.377 & 0.312 & 0.292 \\
\hline & & $(-2.22)$ & $(-2.32)$ & $(-2.34)$ & & $(1.57)$ & (1.29) & $(1.21)$ \\
\hline \multirow[t]{2}{*}{ roa } & & & 2.585 & & & & $11.496 * * *$ & \\
\hline & & & $(1.47)$ & & & & $(4.86)$ & \\
\hline \multirow[t]{2}{*}{ roe } & & & & 1.640 & & & & $5.101 * * *$ \\
\hline & & & & (1.41) & & & & $(3.52)$ \\
\hline \multirow[t]{2}{*}{ tobinq } & $-0.231 * * *$ & $-0.258 * * *$ & $-0.277 * * *$ & $-0.264 * * *$ & $-0.425 * * *$ & $-0.399 * * *$ & $-0.559 * * *$ & $-0.472 * * *$ \\
\hline & $(-5.79)$ & $(-6.19)$ & $(-5.66)$ & $(-5.82)$ & $(-6.47)$ & $(-6.07)$ & $(-7.04)$ & $(-6.46)$ \\
\hline industry & Yes & Yes & Yes & Yes & Yes & Yes & Yes & Yes \\
\hline \multirow[t]{2}{*}{ _cons } & $6.885^{* * *}$ & $6.837 * * *$ & $6.078 * * *$ & $6.433 * * *$ & $9.362 * * *$ & $9.131 * * *$ & $8.192 * * *$ & $8.576 * * *$ \\
\hline & $(5.74)$ & $(5.55)$ & $(5.32)$ & $(5.65)$ & $(5.81)$ & $(5.59)$ & (5.33) & $(5.63)$ \\
\hline Pseudo- $\mathrm{R}^{2}$ & $8.8 \%$ & $9.6 \%$ & $9.4 \%$ & $9.2 \%$ & $13.0 \%$ & $13.8 \%$ & $15.8 \%$ & $14.1 \%$ \\
\hline AUC & 0.697 & 0.702 & 0.701 & 0.699 & 0.776 & 0.776 & 0.790 & 0.778 \\
\hline $\mathrm{N}$ & 896 & 896 & 896 & 896 & 587 & 587 & 587 & 587 \\
\hline
\end{tabular}

Note: (1) ***,** and * indicates statistical significance at level of $0.01,0.05$ and $0.1 ;(2)$ The AUC denotes the area under the ROC curve, and lager AUC value, the better Logistic model fit, normally less than 0.5 indicates that the model is invalid; $0.5-0.6$ shows bad; $0.6-0.7$ can be sufficient; $0.7-0.8$ shows good; 0.8-0.9 indicates very good; 0.9-1.0 shows perfect $\left(\right.$ Okeh, $\left.2012^{[31]}\right)$. 
Table 5. The effect of Government R\&D support on SMEs financial growth

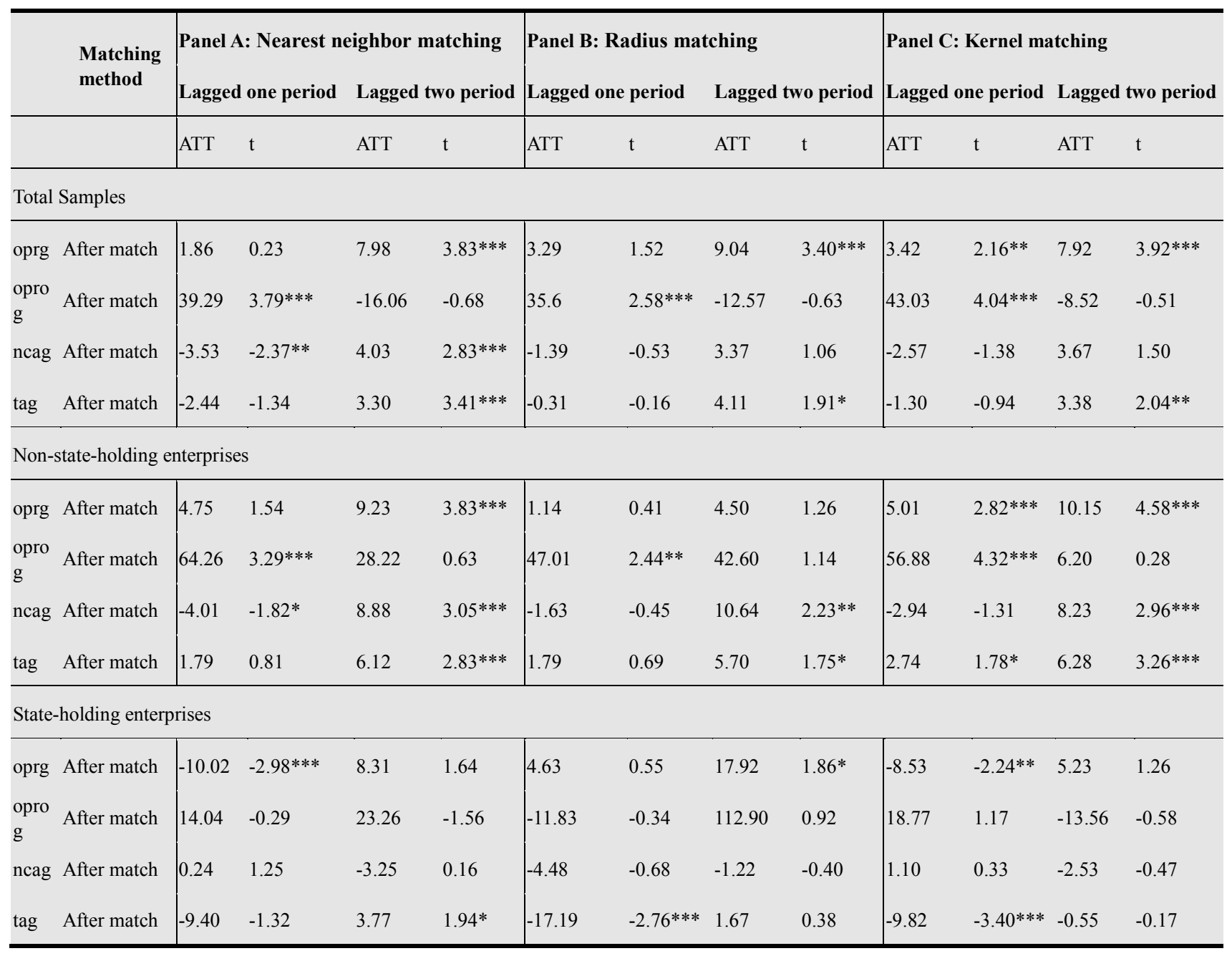

Note: $(1) * * *, * *$ and $*$ indicates statistical significance at level of $0.01,0.05$ and 0.1 , respectively; (2) To save space, we only show the average treatment effect (ATT) after matching and corresponding t-values.

\section{Acknowledgements}

This study is supported by grants from the "Project 211 " Fund of the Central University of Finance and Economics (CUFE) and the Graduates' Innovation Project of CUFE (Approval No.201218); the data collection is conducted with the help of Qiuchan Huang, Liwen Cheng, Xianya Zhang, Changwei Lee, Yazhou Yan and Chuan Chen. The authors appreciate the helpful comments from two anonymous reviewers, and all errors are our own.

\section{References}

[1] Arrow, J. K. (1962). "The Economic implications of learning by doing", The Review of Economic Studies, 29(3):pp.155-173.

[2] Alecke B., T. Mitze. (2011). "Does Firm Size make a Difference? Analysing the Effectiveness of R\&D Subsidies in East Germany", German Economic Review, 13(2): pp.174-195.
[3] Boardman, C. M., W. Bartley and Richard L. Ratliff. (1981). "Small business growth characteristics", American Journal of Small Business, 5(3): pp.33-45.

[4] Becchetti, L. and G. Trovato. (2002). "The determinants of growth for small and medium sized firms. The role of the availability of external finance", Small Business Economics, 19(4):pp.291-306.

[5] Boubakri, N., J. Cosset and O. Guedhami. (2005). "Liberalization, corporate governance and the performance of newly privatized firms", Journal of Corporate Finance, 11: pp.767-790.

[6] Becker, S., A. Ichino. (2002). "Estimation of Average Treatment Effects based on Propensity Scores", Stata Journal, 2(4): pp.358-377.

[7] Corley, E. A. (2007). "A use-and-transformation model for evaluating public R\&D: Illustrations from polycystic ovarian syndrome (PCOS) research", Evaluation and Program Planning, 30: pp.21-35.

[8] Colombo, M.G., L. Grilli, S. Murtinu et al. (2009). "Effects of international R\&D alliances on performance of high-tech start-ups: a longitudinal analysis", Strategic Entrepreneurship Journal, 3: pp.348-370. 
[9] Czarnitzki, D., G. Licht. (2006). "Additionality of public R\&D grants in a transition economy: the case of Eastern Germany", Economics of Transition, 14: pp.101-131.

[10] Czarnitzki D., P. Hanel and J. M. Rosa. (2011). "Evaluating the impact of R\&D tax credits on innovation: A microeconometric study on Canadian firms", Research Policy, 40:pp.217-229.

[11] Chen X., P. Hu. (2005). "The reason and impact of opportunism exist in innovation fund", Science of Science and Management of S.\& T., 12:pp.98-101.陈旭东,胡萍.创 新基金中存在机会主义行为的原因及影响 $[\mathrm{J}]$.科学学与科 学技术管理,2005(12):98-101.

[12] Cerulli Giovanni and B. Potì. (2012). "Evaluating the Robustness of the Effectiveness of Public Subsidies on Firms' R\&D: an Application to Italy", Journal of Applied Economics, Vol XV (2):pp.287-320.

[13] David M. B. and G. J. Stigler. (1957). "The Demand and Supply of Scientific Personnel", NBER Books, National Bureau of Economic Research, Inc, NEW YORK.

[14] Dehejia, R. H. and S. Wahba. (2002). "Propensity Score-Matching Methods for Nonexperimental Causal Studies", Review of Economics and Statistics, 84 (1):pp.151-161

[15] Delmar F., P. Davidsson and W. B. Gartner. (2003). "Arriving at the high-growth firm", Journal of Business Venturing, 18(2):pp.189-216.

[16] Foreman-Peck, J. (2012). "Effectiveness and efficiency of SME innovation policy", (unpublished) Available at IDEAS: http://ideas.repec.org/p/cdf/wpaper/2012-4.html

[17] Goolsbee, A. (1998). "Does Government R\&D Policy Mainly Benefit Scientists and Engineers?" NBER Working Paper No. 6532. (unpublished) Available from: http://www.nber.org/papers/w6532

[18] Gelabert, L., A.Fosfuri, and J. A. Tribo. (2009). "Does the Effect of Public Support for R\&D Depend on the Degree of Appropriability?" Journal of Industrial Economics, 57(4): pp.736-767.

[19] Gu Y., L. Fang. (2006). "Studies on the problems of SME supporting policies system: an empirical analysis on Shanxi exprience”, Enterprises Economy, 18:pp.82-89.顾颖, 房路 生.中小企业支持政策体系问题研究: 基于陕西省经验的 实证分析 [J].经济管理,2006(18):82-89.

[20] Grilli, L. and S. Murtinu. (2012). "Government, Venture Capital and the Growth of European High-Tech Start-Ups: A Firm-Level Panel Data Analysis", (unpublished) Available at SSRN: http://ssrn.com/abstract $=2066867$

[21] Hsu, F.-M., C.-C. Hsueh. (2009). "Measuring relative efficiency of government- sponsored R\&D projects: A three-stage approach", Evaluation and Program Planning, 32:pp.178-186.

[22] Herrera, L., Edna R. Bravo. Ibarra. (2010). "Distribution and effect of R\&D subsidies: A comparative analysis according to firm size", Intangible Capital, 6(2):pp.272-299.

[23] Konings, J. (1997). "Firm Growth and Ownership in Transition Countries", Economics Letters, 55: pp.414.

[24] Kole, S., Mulherin, J.H. (1997). "The government as a shareholder: a case from the United States", Journal of Law and Economics, 40:pp.1-22.

[25] Konings, J., S. Estrin, Z. Zolkiewski et al. (2002). "The Effect of Ownership and Competitive Pressure on Firm Performance in Transition Countries: Micro Evidence from Bulgaria, Romania and Poland",William Davidson Institute Working Paper No.434(unpublished).Available at SSRN: http://ssrn.com/abstract $=307088$

http://dx.doi.org/10.2139/ssrn.307088

[26] Klette, T. J., J. Moen, \& Z. Griliches. (2000). "Do Subsidies to Commercial R\&D Reduce Market Failures? Microeconometric Evaluation Studies", Research Policy, 29(4-5):pp.471-495.

[27] Lerner, J. (2002). "When bureaucrats meet entrepreneurs: The design of effective 'public venture capital' programmes", The Economic Journal, 112: pp.73-84.

[28] Lian Y., Z. Su and Y. Gu. (2011). "Evaluating the effects of equity incentives using PSM: evidence from China", Frontiers of Business Research in China, 5(2): pp.266-290.

[29] Li H., H. Shao. (2012). "The more Government R\&D subsidies, the better? A comparative study based on ownership”, Productivity Research, 7:pp.5-9. 李泓桥,邵海静. 政府给予企业研发补贴越多越好吗?:基于所有制的比较 研究[J].生产力研究,2012(7):5-9.

[30] Marcus, N. and P. Howard. (2003). "Industrial Policy in an Era of Globalization: Lessons from Asia", Institute for International Economics. Available from: http://bookstore.piie.com/book-store/358.html

[31] Okeh U. M., I. E. Ogah, U. S. Okeh and A. Agwu. (2012). "The Use of Receiver Operating Characteristic (Roc) Analysis in the Evaluation of The Performance of Two Binary Diagnostic Tests of Gestational Diabetes Mellitus", International Journal of Asian Social Science, 2(1):pp.35-43.

[32] Penrose, E. T. (1995). "The theory of the growth of the firm", Oxford: Oxford University press.

[33] Rubin, D. B. (1977). "Assignment to treatment group on the basis of covariate", Journal of Educational Statistics, 2:pp.1-26.

[34] Rosenbaum, P. R. and D. B. Rubin. (1983). "Assessing sensitivity to an unobserved binary covariate in an observationalStudy with binary outcome", Journal of the Royal Statistical Society, 45(2): pp.212-218.

[35] Ruegg, R. and I. Feller. (2003). "A toolkit for evaluating public R\&D investment models, methods, and findings from ATP's first decade", Gaithersburg, MD: National Institute of Standards and Technology. NISTGCP 03-857.

[36] Storey, D. J. (1994). "New firm growth and bank financing", Small Business Economics, 6:pp.139-150.

[37] Stein, R. (2005). "The relationship between default prediction and lending profits: Integrating ROC analysis and loan pricing", Journal of Banking and Finance, 29(5):pp.1213-1236.

[38] Tassey, G. (2004). "Policy Issues for R\&D investment in a knowledge-based economy", Journal of Technology Transfer, 29(2): pp.153-185.

[39] Wallsten, S. J. (2000). "The effects of government-industry 
$R \& D$ programs on private $R \& D$ : the case of the small business innovation research program", RAND Journal of Economics, 31:pp.82-100.

[40] Xiao J. and L. Xu. (2007). "Proposed the policy of our government to support SMEs technological innovation", Literary Circles of Cpc History, 10:pp.54-55. 肖居孝, 徐腊梅. 对我国政府支持中小企业技术创新的政策建议[J].党史文 苑,2007(10):54-55.

[41] Yuan H. and X. Chen. (2012). "China's SME policy environment for the growth of SMEs: based on the 384 SMEs empirical data”, Enterprises Economy, 2:pp.176-180.袁红林, 陈小锋.我国中小企业政策与中小企业成长环境的相关性: 基于 384 家中小企业的实证[J].公共管理,2012(2):176-180.

[42] Zhu P., W. Xu. (2003). "The impact of government's S\&T incentive policy on the R\&D input and its patent output of large and medium-sized industrial enterprises in Shanghai", Economic Research Journal, 6:pp.45-53. 朱平芳,徐伟民.政 府的科技激励政策对大中型工业企业 R\&D 投入及其专 利产出的影响: 上海市的实证研究 [J]. 经济研 究,2003,(6):45-53. 